\title{
The Greater the Distance, the Closer You Get
}

\author{
On Teleiopoetry
}

For E.-M. with love from afar

\section{Paradoxical Proximity: A Note on Travelling}

Where exactly are we when we are going to the airport: are we still at home or already travelling afar? Does spatial distance from home, or from persons we feel closely attached to, decrease or actually increase the intensity of our social ties? If essayist Alain de Botton ${ }^{1}$ or sociologists of globalized intimacy like Ulrich Beck and Elisabeth Beck-Gernsheim ${ }^{2}$ could have posed these questions to medieval writers concerning the experience of travelling, they might have replied with a paradox of proximity. In 1127, Hugh of St Victor advised those who seek proficiency in their studies to expand their home country to such an extent that it becomes a place of exile:

delicatus ille est adhuc cui patria dulcis est; fortis autem iam, cui omne solum patria est; perfectus vero, cui mundus totus exsilium est. ille mundo amorem fixit, iste sparsit, hic exstinxit. ${ }^{3}$

(Someone who finds his home country sweet, is still tender; someone who regards every country his home, is already strong. To the truly perfect one, however, the whole world is a place of exile. The tender has attached his love to a certain spot in the world, the strong has dispersed it, the perfect has extinguished it. Hugh of St Victor, Didascalicon, $3: 19,69$ )

1 See Alain de Botton, "On Going to the Airport," in On Seeing and Noticing (London: Penguin, 2005), $10-4$.

2 See Ulrich Beck and Elisabeth Beck-Gernsheim, Fernliebe. Lebensformen im globalen Zeitalter (Berlin: Suhrkamp, 2011).

3 Hugo de Sancto Victore, Didascalicon. De studio legendi. A Critical Text, ed. Charles Henry Buttimer, Studies in Medieval and Renaissance Latin Language and Literature 10 (Washington: Catholic University Press, 1939), 3:19, 69. Unless stated otherwise, all translations in this paper are mine. 
On a literal level, this passage plainly explains the manner in which studies are to be pursued: by seeking the greatest possible distance abroad. On a second, spiritual level, Hugh draws upon an anthropology of alienation prevalent in medieval religious culture: if, in 'perfect' perspective, earthly existence turns out to be mere exile, then detaching oneself from home and from terrestrial matters altogether is a crucial condition for turning one's attention towards eternity. Less obvious (and more interesting) than this religious anthropology, however, is the rhetorical structure of Hugh's argument. While the attributes which introduce the three phrases ascend from delicatus to fortis and eventually perfectus as their linear climax, the relative clauses invert this semantic climax. Spatial terms of social proximity proceed, from the closest (patria) to the furthest social distance (exsilium), yet not without a puzzling turning point. Hugh's phrasing does not simply contrast increasing spiritual perfection with the binding love of worldly dimensions but seems to first parallel both aspects (by extending the love for a specific patria to the love for "omne solum" as patria in the course of strengthening) before finally opposing the concepts of worldly and spiritual home. This is further underpinned by the second sentence, where Hugh goes on to explain: Extinguishing your love for the world ("amorem [...] exstinxit") presupposes its extension (sparsit) as an intermediary step. In relational terms, Hugh's advice thus forms not only a contradiction, but a spatial paradox $:^{5}$ being perfectly at home means to be the most distant from home.

Returning to our initial metaphor of travel, Hugh's spatial paradox carries a remarkable amount of philological baggage. Most notably, Erich Auerbach quoted this passage in his seminal essay on "Philology and Weltiteratur" (1952) to underscore his attempt to counteract both universalist and national definitions of philology:

In any event, our philological home is the earth: it can no longer be the nation. The most priceless and indispensable part of a philologist's heritage is still his own nation's

4 As Jerome Taylor suggests, this reading is supported by Hugh's commentary In Ecclesiasten homiliae (no. 15): "Omnibus mundus exsilium est iis quibus coelum patria esse debuisset [...]. Propterea [...] ut videat homo non esse hic stabilem mansionem, et assuescat paulatim abstrahere animum, et solvere a vinculis terrenarum delectationum" (All the world is a place of exile to those whose home country should be heaven [...]. Therefore [...] man may see that he has no stable home [mansionem] here in the world and may get used to gradually withdrawing his mind and freeing it from the chains of earthly pleasures. Patrologiae cursus completus. Series latina, ed. Jacques Paul Migne, 217 vols. [Paris: Migne 1844-1855], 175:221C-D). Jerome Taylor, The Didascalicon of Hugh of St. Victor (New York: Columbia University Press, 1961), 216n.83-4.

5 Here and in the following, I regard paradoxes not simply as logical contradictions $(a=$ non-a) but propose to subsume by this term any conditions of possibility (expressed or presupposed by communication) which constitute the conditions of their impossibility: e. g., extension of relations with the world (Hugh's patria) constitutes their total loss (exsilium). 
culture and language. Only when he is first separated from this heritage, however, and then transcends it does it become truly effective. We must return, in admittedly altered circumstances, to the knowledge that prenational medieval culture already possessed: the knowledge that the spirit [Geist] is not national. ${ }^{6}$

It goes without saying that Hugh's anthropology of exile and its religious foundations pertain to these "altered circumstances" which separate Auerbach's post-war exile from "prenational medieval culture". After quoting the passage from Hugh's Didascalicon analyzed above, Auerbach ends by pointing towards the opposite direction: "Hugo intended these lines for one whose aim is to free himself from a love of the world. But it is a good way also for one who wishes to earn a proper love for the world."7 Yet Auerbach also draws on Hugh's paradox: rooted in the "indispensable" heritage of "his own nation's culture and language," the philologist needs to transcend the national focus; once perfectus, his heritage is both "truly effective" and distant at the same time - or more precisely: effective by virtue of distance. Clearly echoing Hugh's spatial paradox, Auerbach's cosmopolitan "home" of philology also turns out to be a paradoxical habitat of proximity and distance. ${ }^{8}$

As I hope to demonstrate in this paper, Hugh's spatial paradox of home and exile (as well as its reception by Auerbach) is by no means a singular example; in fact, we can find instances of this paradox in a plethora of medieval texts. As it can be traced across various genres, languages, discourses and media, we may assume that it fulfils an important function in the cultural production of space. If so, it has escaped comparative analysis to date. Literary scholars have detected this paradox in the spatial structure of particular genres - above all in the troubadours' praise of 'distant love'/love from afar' ("amor de loing") ${ }^{9}$ and in travelogues such as the Middle High German Herzog Ernst. As Markus Stock has shown, the story of the protagonist's political rebellion against Emperor Otto

6 Erich Auerbach, "Philology and Weltliteratur," The Centennial Review 13 (1969), 1-17, 17.

7 Ibid.

8 Auerbach himself reflects this paradox as a fragile balance between contraction and extension of scope: "But the more our earth grows closer together, the more must historicist synthesis balance the contraction by expanding its activity. To make men conscious of themselves in their own history is a great task, yet the task is small [...] when one considers that man not only lives on earth, but that he is in the world and in the universe." Ibid.

9 See the classic study by Leo Spitzer, L'amour lointain de Jaufré Rudel et le sens de la poésie des troubadours, University of North Carolina Studies in the Romance Languages and Literature 5 (Chapel Hill: University of North Carolina Press, 1944); for recent discussions of this concept and its use in troubadour songs, see Ulrich Wyss, "Amour de loin" in Projektion - Reflexion Ferne. Räumliche Vorstellungen und Denkfiguren im Mittelalter, ed. Sonja Glauch, Susanne Köbele and Uta Störmer-Caysa (Berlin and New York: de Gruyter, 2011), 161 - 71; Jan Söffner, "Liebe als Distanz. Die 'Fernliebe' bei Jaufre Rudel," in Der Tod der Nachtigall. Liebe als Selbstreflexivität von Kunst, ed. Martin Baisch and Beatrice Trinca, Berliner Mittelalter- und Frühneuzeitstudien 6 (Berlin: de Gruyter, 2009), 55-81 and section IV of this paper. 
and his successive reintegration into feudal society unfolds a bipartite narrative structure of intertwined spaces. ${ }^{10}$ Ernst's rise and fall in the first part of the story take place in Bavaria. After his attempted assassination of the emperor, duke Ernst flees into an imaginary oriental exile; leaving the "world of history" behind, the tempest-tossed fugitive enters a "world of fable" where he encounters the wondrous monsters of the East. ${ }^{11}$

However, instead of transporting the hero into an adventurous otherworld, the orient confronts Ernst with exactly the same problems he seemed to have left behind. After causing a massacre among the crane people of Grippia which echoes his former diplomatic failure and political attack, Ernst finally assists the cyclopes of Arimaspi in their war against a neighbouring tribe of monstrous creatures, thereby displaying the perfect loyalty and commitment (triuwe) he once lacked. For Ernst (and the reader alike), the monstrous "world of fable" serves as a "space of reflection" in Stock's phrasing, leading from the symbolic "repetition of the crisis" in an exotic space towards a successful "reflection on the empire." ${ }^{12}$ Ernst and his companions are therefore far from being "Christian tourists," as Albrecht Classen suggested: ${ }^{13}$ while ostensibly leaving his problems behind, we might conclude, Ernst, in fact, symbolically returns to them as spatial distance grows. Or, to put it more paradoxically: the greater the distance, the closer you get.

It should be noted that this socio-spatial paradox is not exclusively dependent on the twofold narrative structure of the text, nor are the hybrid "liminal spaces" on which it relies unique to Herzog Ernst. ${ }^{14}$ On the contrary, Augustine, Isidore of Seville and other writers corroborate that the medieval discourse on monstrosity in general correlates topological distance with increased reflexive significance. Monsters can serve as symbolic media for anthropology, theology or epistemology, not despite the fact that they are located in the distant reaches of the world but because of it. ${ }^{15}$

10 See Markus Stock, Kombinationssinn. Narrative Strukturexperimente im 'Straßburger Alexander,' im 'Herzog Ernst B' und im 'König Rother', Münchener Texte und Untersuchungen zur deutschen Literatur des Mittelalters 123 (Tübingen: Niemeyer, 2002), 149-228.

11 Ibid., 170.

12 Ibid., 215, 217 (my translations).

13 Albrecht Classen, "The Crusader as Lover and Tourist. Utopian Elements in Late Medieval German Literature. From Herzog Ernst to Reinfried von Braunschweig and Fortunatus," in Current Topics in Medieval German Literature. Texts and Analyses, ed. Sibylle Jefferis, Göppinger Arbeiten zur Germanistik 748 (Göppingen: Kümmerle, 2008), 83 - 102, 85.

14 See Rasma Lazda-Cazers, "Hybridity and Liminality in Herzog Ernst B," Daphnis 33 (2004), $53-78$.

15 However exceptional physical disabilities or deformations may appear in individual cases, for Augustine the existence of monstrous people confirms their status as a normal option of God's creation; monsters can serve as an argument against anthropological discontinuity, as they may form whole peoples in far-away countries; see Augustine, City of God (16:8). In 
Consequently, I would like to suggest that we first widen our scope in search of these spatial paradoxes beyond single texts and genres and second, that we should develop analytical terms and concepts that can help us study their function in cultural perspective. The following remarks will try to explore some of these spatial concepts, practices and media that I find useful to subsume under the heading of 'teleiopoetry' - a term borrowed from Jacques Derrida, which resonates with spatial paradox and which can be reinscribed into a theoretical framework apt for this task. Defining teleiopoetry as the 'literary production of proximity through distance' (as provisional as this might be at this point), I hope to prove the theoretical power of such a concept. It may help us recognize not only general practices in the cultural production of space shared across texts and genres, languages or media which are usually separated by specialist analyses. Moreover, the concept of teleiopoetry could help us clarify why medieval cultures favour these paradoxes of 'close distance'.

\section{Love Songs as Teleiopoetry: Two Examples from German Minnesang}

From the presumed beginnings of Middle High German love poetry in the twelfth century onward, distance and desire couple to form a potent, yet underestimated model of teleiopoetry. ${ }^{16}$ Older research considered German Min-

temporal perspective, Isidore also classifies monsters by means of distance-related terms: "Portents are also called signs, omens, and prodigies, because they are seen to portend and display, indicate and predict future events. The term 'portent' (portentum) is said to be derived from foreshadowing (portendere), that is, from 'showing beforehand' (praeostendere). 'Signs' (ostentum), because they seem to show (ostendere) a future event. Prodigies (prodigium) are so called, because they 'speak hereafter' (porro dicere), that is, they predict the future." Translation quoted from The Etymologies of Isidore of Seville, ed. and trans. Stephen A. Barney et al. (Cambridge: Cambridge University Press, 2007), 243 - 4 (11:3:2 -3). To be sure, the practice of relating monstrosity to spatial and/or temporal distance goes back to antiquity; see, for instance, Pliny, Naturalis historia (7:1:1-7:2:32). As Werner Röcke noticed, medieval writers continue to locate monsters in distant places but, paradoxically ("auf eine höchst widersprüchliche Weise"), include the excluded in their discourse. Werner Röcke, "Erdrandbewohner und Wunderzeichen. Deutungsmuster von Alterität in der Literatur des Mittelalters," in Der fremdgewordene Text. Festschrift für Helmut Brackert zum 65. Geburtstag, ed. Silvia Bovenschen et al. (Berlin: de Gruyter, 1997), 265-84, 269.

16 Compared to the concept of amor de loing in Provençal poetry, Fernliebe in German Minnesang has traditionally been neglected: "Im Unterschied zur französischen Trobadorlyrik spielt [...] die eigentliche Fernliebe, die eine weite räumliche Distanz der Liebenden voraussetzt, im deutschen Minnesang keine Rolle." Horst Wenzel, "Fernliebe und Hohe Minne. Zur räumlichen und zur sozialen Distanz in der Minnethematik," in Liebe als Literatur. Aufsätze zur erotischen Dichtung in Deutschland, ed. Rüdiger Krohn (München: Beck, 1983), 187-208, 193. As I shall subsequently argue, this judgment is based on a narrow socio- 
nesang and its subgenres to be characterized by two separate (and mutually exclusive) sets of spatial practices. The first set comprised singers and lovers insisting on irreconcilable spatial, bodily and communicative distance from their desired others. The place of courtly love in Minnesang is virtual: it occurs in dreams, in an ever expanding human interiority of the heart or muot. ${ }^{17}$ Since the object of desire, the Lady, is absent, Minnesingers are thrown back at themselves, their singing and their production of erotic discourse: "Si hât leider selten / mîne klagende rede vernomen. / des muoz ich engelten. / nie kunde ich ir nâher komen" (alas, she never heard my lament, therefore I must suffer. I could never get closer to her), as Reinmar laments. ${ }^{18}$ Giving rise both to the joy of the singer and the referential conflict of the lover, the distance of the desired seems the dominant prerequisite of a proximity to the self, exhibited in the singer's expression of interiority.

Contrarily, the second set, including the parodic songs of Hartmann, Steinmar and Neidhart and the Dawn Songs of Wolfram von Eschenbach, invokes or even displays fulfilled proximity. ${ }^{19}$ Here, love's place was seen as excluded from social visibility or transported to liminal spaces - to rural scenarios (in Neidhart's oeuvre) or to the break of day, which literally merges the lovers in an undisguised last sexual act (as in Wolfram's Dawn Songs): even if there were three suns, they could not force a single ray of light between the two lovers (MF 8,28-9); even the best sculptor could not render their unity (MF 3,29-30). According to this older view, it was the achievement of Walther von der Vogelweide to unmask and overcome this dichotomy of distance and proximity and

functional concept of distance love that fails to grasp the general production of proximity through distance. For a revision of Wenzel's approach, see Franz Josef Worstbrock, "Fernliebe. Allgemeines und Besonderes zur Geschichte einer literarischen Konstruktion," in Projektion - Reflexion - Ferne (see note 9), 137-59, esp. 141-2.

17 In older research, this virtualization was discussed as an educational or sublimating function of love poetry; for a revision of this debate see Harald Haferland, Hohe Minne. Zur Beschreibung der Minnekanzone, Beiheft zur Zeitschrift für Deutsche Philologie 10 (Berlin: Schmidt, 2000), $283-4$.

18 Reinmar, Ich wil allez gâhen, in Des Minnesangs Frühling. Unter Benutzung der Ausgaben von Karl Lachmann und Moriz Haupt, Friedrich Vogt und Carl von Kraus, ed. Hugo Moser and Helmut Tervooren, 38th ed. (Stuttgart: Hirzel, 1988), 330 (no. XIX; 170,22-5). In the following, all references to "MF" refer to this edition.

19 See Hartmann's song MF 216,29-217,13; Wolfram: MF 3,1-32; 4,8-5,15; 7,41-9,3; Steinmar: Die Schweizer Minnesänger. Nach der Ausgabe von Karl Bartsch, ed. Max Schiendorfer (Tübingen: Niemeyer, 1990), no. 26. On Reinmar's and Neidhart's parodies see, with further references to the research history, Gert Hübner, Minnesang im 13. Jahrhundert, Narr Studienbücher (Tübingen: Narr, 2008), 45-61 and 125-31. For critical discussions of this (older) dichotomy between Dawn Songs and Minnesang see Christoph Cormeau, "Zur Stellung des Tagelieds im Minnesang," in Festschrift Walter Haug und Burghart Wachinger, ed. Johannes Janota and Paul Sappler, 2 vols. (Tübingen: Niemeyer, 1992), 2:695-708. 
their spatial metaphors: "wirb ich nider, wirb ich hôhe, ich bin versêret" (whether I am wooing low or high, I am wounded in any case). ${ }^{20}$

In the last decades, research has begun to revise this (simplified) dichotomy of distance and proximity, because it excludes fundamental paradoxes. Peter Strohschneider has drawn critical attention to the fact that many songs deliberately play with the discrepancy between the joyful artistic expression of the singer and the distant emotions of the lover, thereby unveiling the purported distance of the desired as an act of simultaneous performative presence and referential distance ${ }^{21}$ - notably in Reinmar, as Jan-Dirk Müller has emphasized. ${ }^{22}$ Other studies have shed light on the paradoxical intimacy running through both classical Minnesang and Dawn Songs (albeit from different directions). Even for his artistic self-reference, Reinmar employs metaphors of sexual presence (e.g., bîligen in MF 166,14-5) - the lover's propositions of distance consequently rely on the singer's rhetoric of proximity. Conversely, the lovers of Wolfram's Dawn Songs reach physical and aesthetic extremes of proximity only under the condition of the imminent spatial distancing of the man and the intrusion of others. ${ }^{23}$ Both subgenres, wooing songs like Dawn Songs, combine distance and intimacy, although on different levels. This can be witnessed far beyond the classical period, as Oswald von Wolkenstein's Dawn Song Ain tunckle farb von occident vividly displays. With considerable rhetorical effort Oswald stages his desire for his absent lady Margarete - a lady he is, in fact, already married to (if we subscribe to the biographical portrait produced by Oswald's songs). Even under the conditions of the closest legitimate relations, we may therefore conclude, lovers seek distance - the closer you are, the greater the need of distancing.

These are by no means scattered examples. On the contrary, many songs not only reflect these spatial paradoxes but even build their entire poetic strategies upon them. The German Minnesinger Rudolf von Fenis, documented as count of Neuchâtel between 1158 and 1192, offers a particularly interesting case for a more precise analysis. ${ }^{24}$ In its first two stanzas, Rudolf's Mit sange wânde ich

20 Walther von der Vogelweide, Leich, Lieder, Sangsprüche. 14., völlig neubearb. Auflage der Ausgabe Karl Lachmanns, ed. Christoph Cormeau (Berlin: de Gruyter, 1996), 96 (Aller werdekeit ein füegerinne, no. 23a).

21 See Peter Strohschneider, “'nu sehent, wie der singet!' Vom Hervortreten des Sängers im Minnesang," in 'Aufführung' und 'Schrift' in Mittelalter und Früher Neuzeit, ed. Jan-Dirk Müller, Germanistische Symposien. Berichtsbände 17 (Stuttgart: Metzler, 1996), 7 - 30.

22 See Jan-Dirk Müller, "Performativer Selbstwiderspruch. Zu einer Redefigur bei Reinmar," Beiträge zur Geschichte der deutschen Sprache und Literatur 121 (1999), 379-405.

23 See Christian Kiening, "Poetik des Dritten," in Zwischen Körper und Schrift. Texte vor dem Zeitalter der Literatur (Frankfurt am Main: Fischer, 2003), 157-75.

24 For biographical information, see Helmut Tervooren, "Graf Rudolf von Fenis-Neuenburg," in Die deutsche Literatur des Mittelalters. Verfasserlexikon, ed. Kurt Ruh, 2nd ed., vol 8 (Berlin: de Gruyter, 1992), 345 -51. With particular reference to Rudolf's reception of Romance poetry and the numerous borrowings of MF 81,30-82,25, see Helen Stadler, "Rudolf 
mîne sorge krenken (MF 81,30-82,25) exposes well-established paradoxes of courtly love poetry. To soothe his sorrows (of rejection?) and to detach himself from them, ${ }^{25}$ he starts singing; yet the more he sings and reflects on them, the less he can dispel them: "sô ich ie mêre singe und ir ie baz gedenke / sô mugent si mit sange leider niht zergân." Minne, the personification of love, had raised his ambition and, as if it were a gift of honour, commanded him to enshrine his lady, who could turn his sorrow into joy, in his heart. ${ }^{26}$ Since all verbal reflections (I,3: gedenke) hark back to their sole source of sorrow, poetry offers no remedium amoris.

To resolve this paradox, Rudolf refers to a meta-poetic solution: "Ich wil mînen kumber ouch minnen klagen" - you may cut across the opposition of joy and sorrow if you address your lament to love herself.

Although ostensibly solved, the paradox nevertheless remains, as illustrated by Rudolf's spatial metaphors: while love includes the beloved in his heart (II,2), the singer, in turn, yearns to be introduced by her into the "house of joy" (II,7: "ze vröiden hûs") by her. Paradoxically, the lover imagines himself both as including and (potentially) included.

This latent spatial paradox only becomes manifest in the subsequent stanzas III and IV:

Mich wundert des, wie mich mîn vrowe twinge

so sêre, swenne ich verre von ir bin.

sô gedenke ich mir - und ist mîn gedinge -,

mües ich sî sehen, mîn sorge waere dahin.

'Sô ich bî ir bin', des troestet sich mîn sin

unde waene des, daz mir wol gelinge.

alrêst mêret sich mîn ungewin.

von Fenis and his Sources", Oxford German Studies 8 (1973/74), 5 - 19, and Volker Mertens, "Dialog über die Grenzen: Minnesänger - Trobadors - Trouvères. Intertextualität in den Liebesliedern Rudolfs von Fenis," in Kritische Fragen an die Tradition. Festschrift für Claus Träger zum 70. Geburtstag, ed. Marion Marquardt, Stuttgarter Arbeiten zur Germanistik 340 (Stuttgart: Heinz, 1997), 15-41.

25 Lines I,2-3 are already deeply ambiguous: "dar umbe singe ich, daz ich sî wolte lân.” Does the pronoun "sî" refer to his aforementioned sorrows? Or should we read $s \hat{\imath}$ (and ir in line I,3) as a veiled reference to their source, i. e. his lady? Both options seem possible up to the 4 th line which grammatically excludes the second option.

26 The motif of the 'lady in the heart' is central for reflections on metaphorical and physical space in courtly and religious literature alike; see Xenja von Ertzdorff, "Die Dame im Herzen und Das Herz bei der Dame. Zur Verwendung des Begriffs 'Herz' in der höfischen Liebeslyrik," Zeitschrift für deutsche Philologie 84 (1965), 6-46, and Nigel Palmer, “'Herzeliebe', weltlich und geistlich. Zur Metaphorik vom 'Einwohnen im Herzen' bei Wolfram von Eschenbach, Juliana von Cornillon, Hugo von Langenstein und Gertrud von Helfta," in Innenräume in der Literatur des deutschen Mittelalters. XIX. Anglo-German Colloquium Oxford 2005, ed. Burkhard Hasebrink et al. (Tübingen: Niemeyer, 2008), 197-224. 
(I wonder how my lady compels me so much whenever I am far from her. Then I think to myself, hopefully, if I could see her, my sorrow would be gone. 'When I am near her' thus my mind consoles itself and hopes for success. Now this only increases my loss. MF $82,5-11)$

Whenever he seeks distance, the poet notices to his own surprise ("mich wundert des"), his lady gains influence over him by attracting his thoughts ("gedenke") and dominating his intentions ("gedinge"). In this case, the spatial paradox is articulated through the language of physical violence and power: How can the lady force or even besiege ("twinge") the I if the singer is beyond her immediate spatial reach ("verre von ir")? Second-order reflections on conditional, virtualized proximity promise comfort (III,5), but this option turns out to be deceptive as well, for it only increases the paradox: "alrêst mêret sich mîn ungewin" - thinking and singing about her presence simply intensifies the loss of absence, at least under the conditions of referential language and desire ("unde waene des, daz mir wol gelinge").

Leaping from virtual to real proximity, ${ }^{27}$ Rudolf now discusses the antithesis in overtly dialectical fashion:

Sô ich bî ir bin, mîn sorge ist deste mêre,

alse der sich nâhe biutet zuo der gluot,

der brennet sich von rehte harte sêre.

ir grôze güete mir daz selbe tuot.

Swenne ich bî ir bin, daz toetet mir den muot,

und stirbe aber rehte, swenne ich von ir kêre,

wan mich daz sehen dunket alsô guot.

(When I am near her my sorrow grows even more just like someone who gets close to the fire gets severe burns, and rightly so. Her perfection does the same to me. Whenever I am near her, it kills my mind - but I die all the more whenever I turn from her, for viewing seems so good to me. MF 82,12-8)

Neither distance nor proximity seem advisable (or even possible) per se: while her absence draws my mind to her, her presence will burn my thoughts. Distance leads towards proximity, proximity in turn requires distance - but any single

27 Or, more precisely, from virtualized imagination to imagined reality. Of course, the punctuation of line 3,5 was introduced by earlier editors of Minnesangs Frühling, namely Karl Lachmann and Friedrich Vogt; it cannot be found in the manuscripts. In view of Rudolf's abrupt transition from distance (3,2: "swenne ich verre von ir bin") to proximity (3,5: "[s]ô ich bî ir bin"), Max Hermann Jellinek's early vote for inverted commas is revealing: "ich empfinde es [...] als einen unerträglichen bruch, dass mit dem so ich bî ir bin [...] die situation sich jäh ändert. erst ist der dichter fern von der geliebten und stellt sich vor, wie es sein würde, wenn er bei ihr wäre, in zeile 9 ist er plötzlich in ihrer gegenwart;" Max Hermann Jellinek, "Zu Minnesangs Frühling," Zeitschrift für deutsches Altertum und Literatur 55 (1917), $372-7,375$. Modern punctuation thus reduces the spatial rupture documented in the medieval transmission of the text and witnessed by Jellinek. 
position will be lethal. Again, we find Rudolf balancing a spatial paradox. But whereas the first stanzas are dominated by the performance of lament (I-II) and rational reflection (III), visuality (sehen) now comes to the fore as a medium to bridge the gap between the distant object and the experiencing self.

The last stanza (V) further elaborates the spatial paradox of proximity through distance and visuality by means of an allegorical comparison. Her beautiful, embodied presence caused such attraction, the poet-lover remembers, that it was like that of the proverbial flame for the moth: "diu vliuget dâr an, unze sî sich gar verbrennet" (it draws nearer to the fire until it burns to death). This is how her great güete seduced me, Rudolf concludes in exact structural parallel with the preceding stanza $(\mathrm{IV}, 4)$, and continues to condemn his foolish heart for having driven him 'that far' ("sô verre").

Much could be added about Rudolf's subtle metaphorical shifts from distant visuality to a perilous epistemology of beauty, from the lady's "grôze güete" $(\mathrm{IV}, 4 ; \mathrm{V}, 4)$ to her bodily appearance (V,1: "ir schoenen lîp"), from the heart as an interior space $(\mathrm{II}, 2)$ to an organ of misled perception $(\mathrm{V}, 5)$. With regard to spatial paradoxes, however, the overall structure of the song as a whole is more significant. Distance and proximity not only constitute the central topic on a propositional level, but also on rhetorical and conceptual levels. Rudolf's song produces acts of distance as it substitutes the emotional involvement of the puzzled lover (especially in III) for argumentation, analytical comparison and evaluative judgement (IV - V); in its course, the song attempts to de-paradoxify the interrelation of distance and proximity by singing (I,3: "singe[n]"), rational virtualization (III,3: "gedenke[n]"), and seeing (IV,7: “sehen"). ${ }^{28}$

Opposed to this, we can observe highly self-referential structures that interweave the stanzas on the "poetic" level, as Roman Jakobson would have called it. $^{29}$ Certain linguistic elements run across the whole song and thereby produce proximity through the combination of signs, often supported by structural correspondences of the canzona form: "mîn[e] sorge" (I,1; III,4), "gedenke[n]" (I,3; III,3), "minne" (I,5; II,1), "herze" (II,2; V,5), the phrase "sô / swenne ich bî ir bin" (III,5; IV,1; IV,5) and "ir grôze güete" (IV,4; V,4) closely connect the stanzas. Semantic changes notwithstanding, we may find the paradox of distance and proximity reproduced in linguistic structures. Rudolf's discourse on distance is supported by a poetics of proximity.

28 These models are frequently used in Minnesang, too - for the model of rational virtualization see, most concisely, Friedrich's von Hausen Ich denke underwîlen: "sô vröwe ich mich doch sêre, / daz mir nieman kan / erwern, ich gedenke ir nâhe, / swar ich landes kêre" (I am truly happy that nobody can prevent me from getting close to her by means of thought wherever [to which country ever] I turn, MF 52,28-31).

29 See Roman Jakobson, "Closing Statement: Linguistics and Poetics," in Style in Language, ed. Thomas A. Sebeok (Cambridge, Mass.: MIT Print, 1960), 350-77. 
We may draw at least three conclusions from this example. Firstly, Rudolf's song displays a complex strategy of producing social interrelations by means of symbolic space, with distance and proximity encoded on multiple levels (propositional, conceptual, rhetorical, and poetic). Secondly, these spatial aspects clearly exceed the mere production of social hierarchy and an idealized feminine position, as suggested by older research on the motif of Fernminne, ${ }^{30}$ but also undermine the dichotomy of distance versus proximity. Therefore, and this is my third point, we need new theoretical approaches that could account for the intricate productivity of the spatial paradox.

Courtly love poetry demonstrates a remarkable variety and thereby the creative potential of this paradox. This is even the more remarkable in view of the fact that up to the thirteenth century, courtly literary communication is embedded in face-to-face interactions among persons co-present in space. Given these circumstances, Minnesingers are obsessed with paradoxifying this presence by referring to distant others, as my second example demonstrates.

Heinrich von Morungen favours many spatial concepts already observable in Rudolf, first and foremost the model of seeing. Ingrid Kasten, Christopher Young and Christoph Huber have pointed out that Heinrich's visual poetics of seeing and showing (schouwen) oscillate between imagination and the dissolution of its metaphorical images, between intensified sensuality and the spirituality of abstraction. ${ }^{31}$ I would like to argue that we can frame this well-established tension as a spatial effect, one which has thus far received less attention: descriptive proximity and discoursive distance from the lady may be understood as another version of the spatial paradox exposed by language. ${ }^{32}$

30 See, for example, Wenzel, "Fernliebe" (see note 16), 201.

31 See Ingrid Kasten, Frauendienst bei Trobadors und Minnesängern im 12. Jahrhundert. Zur Entwicklung und Adaption eines literarischen Konzepts, Germanisch-romanische Monatsschrift. Beihefte 5 (Heidelberg: Winter, 1986), 319-29; Christopher Young, "Vision and Discourse in the Poems of Heinrich von Morungen," in Blütezeit. Festschrift für L. Peter Johnson, ed. Mark Chinca, Joachim Heinzle, and Christopher Young (Tübingen: Niemeyer, 2000), 29-51; Christoph Huber, "Ekphrasis-Aspekte im Minnesang. Zur Poetik der Visualisierung bei Heinrich von Morungen mit Blick auf die Carmina Burana und Walther von der Vogelweide," in Der Tod der Nachtigall (see note 9), 83-104; with special emphasis on metaphor, see also Christoph Leuchter, Dichten im Uneigentlichen. Zur Metaphorik und Poetik Heinrichs von Morungen, Beiträge zur Mittelalterforschung 3 (Frankfurt am Main: Peter Lang, 2003).

32 Commenting on Heinrich's Mir ist geschehen als einem kindelîne (MF 145,1-32), Young notes "the inescapable paradoxical state of the singer" expressed by the song's imagery: "he must distance himself from his lady but at the same time he cannot let go of her." In Young's view, this still leaves us with a puzzle: "At this point the reason 'why' he must distance himself from his lady remains unclear." Young, "Vision and Discourse" (see note 31), 37. As Franziska Wenzel argued, this spatial paradox secures the reproduction of the lament and may therefore be regarded as a fundamental poetological condition: see Franziska Wenzel, "Die alte 'niuwe' Klage: Reflexionen über die Folgen narzißtischer Begierde in der Minneklage 
We may apprehend this idea from a simple one-verse thought experiment that combines metaphors of killing and death with an argument on transcendence:

Vil süeziu senftiu toeterinne,

war umbe welt ir toeten mir den lîp,

und ich iuch sô herzeclîchen minne,

zwâre vrouwe, vür elliu wîp?

Waenent ir, ob ir mich toetet,

daz ich iuch iemer mêr beschouwe?

nein, iuwer minne hât mich des ernoetet,

daz iuwer sêle ist mîner sêle vrouwe.

sol mir hie niht guot geschehen

von iuwerm werden lîbe,

sô muoz mîn sêle iu des verjehen,

dazs iuwerre sêle dienet dort als einem reinen wîbe.

(Sweet gentle murderess, why do you want to kill me - even though I love you, my lady, truly more than every other woman? Do you believe that, by killing me, you would prevent me from ever setting eyes on you again? No, your love has made your soul my soul's lady. If I receive nothing good from you here, my soul will vow to serve your soul as a perfect woman there. MF 147,4-15)

The pragmatic force of this song results from an interesting spatio-temporal projection. Rejected in this life (hie), the singer promises to court his lady's soul in the hereafter (dort). As Christopher Young rightly notes, "[t]his is far from an innocent statement of undying love." 33 "The singer is playing on the notion of eternal service to show the lady that he is in control: even if she wants to be rid of him, his soul will be waiting for hers on the other side of death." ${ }^{34}$ With regard to this life (hie), this implies no less than a threat: you better comply with my desire since you will not escape my transcendent double anyway - "aus diesem Kreis [...] gibt es kein Entrinnen," as Sabine Obermaier comments. ${ }^{35}$ As in other

Heinrichs von Morungen," in Institutionelle Ordnungen zwischen Verstetigung und Transformation, ed. Stephan Müller, Gary S. Schaal, and Claudia Tiersch (Köln: Böhlau, 2002), $211-22$.

33 Young, "Vision and discourse" (see note 31), 49; Young's statement - and my reading - run contrary to traditional interpretations of this song; see the references to older scholarship mentioned in ibid., 49-50n78; on the contrary, Kasten, Frauendienst (see note 31), 328-9 reads Heinrich's argument about eternal continuity of service as directed towards transcendence: it displays "daß sich das Verlangen nach absoluter Liebe nicht hie, nicht im Diesseits, verwirklichen kann." Ibid., 239.

34 Young, "Vision and discourse" (see note 31), 49-50; with a similar conclusion (though without reference to Young) Leuchter, Dichten im Uneigentlichen (see note 31), 122.

35 Sabine Obermaier regards this as "ein perfektes Dilemma." Sabine Obermaier, "Möglichkeiten und Grenzen der Interpretation von 'Dichtung über Dichtung' als Schlüssel für eine Poetik mittelhochdeutscher Lyrik. Eine Skizze," in Mittelalterliche Lyrik: Probleme der 
songs, Heinrich von Morungen thus extends the frame of wooing beyond the grave. ${ }^{36}$ What makes Vil süeziu senftiu toeterinne a particularly revealing case, however, is that we can observe its spatial paradox in the making: the singer transcends the situation of communication both temporally and spatially, yet without loosening the connection to his lady, the implied addressee. ${ }^{37}$ On the contrary, such virtual extension actually intensifies social relations by making acts of rejection less probable - or succinctly: the greater the distance you create (towards a transcendent dort), the closer your grip (hie).

These two examples only touch on a much broader phenomenon of teleiopoetry, or the production of proximity through distance, which still remains to be discovered - especially beyond the generic limits of love poetry. As my readings suggest, it could be useful to analyze its paradoxes on different levels, at least on conceptual (cognitive organization of information), propositional (exterior references of utterances), rhetorical (forms and practices of speech) and poetic levels of texts (combinations of signs). Furthermore, one needs to distinguish different aspects on each level, such as the time or duration, place or location, mode, frequency, media, limiting semantics and entities involved; since 'spatial' paradoxes as those observed in the previous examples involve more than the category of 'space' in the narrower, Cartesian sense. Combining these parameters, it becomes possible to create a matrix to analyze teleiopoietic practices on a wider scale. As a first (merely exemplary, not exhaustive) sample, we may draw on the corpus of twelfth-century German Minnesang collected in Des Minnesangs Frühling to identify some of the most prominent elements of teleiopoietic constellations:

- Time/duration: Singers may equally look back in remembrance or anticipate futures (MF 104,6); they refer to nights gone by and days approaching (Wolfram's Sîne klawen in MF 4,8-5,15; Wolfram's Ez ist nu tac in MF 7,41 - 9,3; MF 143,22-144,17); they long indefinitely "mit staeteclîchen triuwen" (MF 159,13; 169,16-7) or deliberately instruct their sons or heirs to act on their behalf after they are gone (MF 125,10-8; Wolfram's Maniger klaget in MF, line 2,10); their love-relations stretch from early childhood (MF $90,16-7 ; 134,29-30$ ) to old age, death and beyond (MF 147,4-15; 168,30;

Poetik, ed. Thomas Cramer and Ingrid Kasten, Philologische Studien und Quellen 154 (Berlin: Schmidt, 1999), 11-32, 24.

36 See, for instance, Sach ieman die vrouwen (MF 129,35-130,8).

37 "Nähe in der Trennung" as an example of Heinrich's "Poetik des Paradoxen" (to quote Sabine Obermaier) is thus established on the basis of ontological speculation that opposes soul versus body, contingent versus eternal proximity and mundane reality versus transcendence. See Obermaier, "Grenzen der Interpretation" (see note 35), 24. For the transcendent quality of desire in Heinrich von Morungen, see also Jan-Dirk Müller, "Beneidenswerter kumber," Deutsche Vierteljahrsschrift für Literaturwissenschaft und Geistesgeschichte 82 (2008), $220-36$. 
$173,34-174,2 ; 175,27-8 ; 199,18-24)$, they or their ladies age and bemoan the passing of life (MF 152,15-24;156,27-157,30), sometimes they are more specific and count the hours, days, seasons, up to 1,000 years of wooing (MF 75,$32 ; 84,26-7 ; 104,6-8 ; 188,31-189,4 ; 197,35 ; 208,20-1 ; 209,13-4$; $217,38-218,4$ ); or they project open time spans (MF 135,9-10).

- Places/locations: $:^{38}$ Minnesingers project foreign countries far from home (Kürenberger's MF 9,2-3; MF 52,25-31; 92,8; 116,1-4; 156,15; 211,20-6), beyond the raging sea (MF 87,16; 182,23-5), in Italy (MF 115,1), but also, especially though not exclusively in Dawn Songs, they imagine castle architectures (Wolfram's Von der zinnen in MF 6,10-1; Wolfram's Ez ist nu tac in MF 8,1-2; MF 138,31-2) and interiors (Wolfram's Den morgenblic in MF $3,12-3)$; sometimes they insist on places neither far nor near (MF 161,21 -2) or they seek but cannot reach distance from their lady (MF 52,15-6; Hartmann's Dir hât enboten, vrowe guot in MF, line 3,5).

- Modes: in creating such spaces, singers/lovers feel forced by their lady (twingen, dienen, etc.) or liberated by the mental freedom of thoughts (MF $51,33-52,36)$, they refer to realistic exterior topographies as well as to virtual spaces of dreams (MF 48,23-31; 145,9-12), wishes and fears (MF 145,1724).

- Frequency: they iterate and renew distances ("erniuwen," MF 133,15; $166,16-7 ; 187,31-2 ; 189,11-3$ ) or reach their lady once (MF 159,37-40) or never (MF 158,8-10;170,25).

- Media: to produce and communicate proximity through distance they involve media such as writing and tombstones (MF 129,36-130,8), mirrors (MF $137,2-3 ; 145,1-4$ and 22-4), windows (Wolfram's Den morgenblic in MF 3,12; Wolfram's Sîne klâwen in MF 5,6-7; MF 129,14-6; 144,24-5), glances (MF 129,14-6;133,13 and 137,37-134,1;164,26-9), voices and songs of others (Wolfram's Sîne klâwen in MF 5,8-9; Kürenberger's MF 8,3-6; MF 164,24; Gottfried's Diu zît ist wunneclich), intermediary messengers (MF

38 With Michel de Certeau, I distinguish the general production of space from places in the topological sense: "A place (lieu) is the order (of whatever kind) in accord with which elements are distributed in relationships of coexistence. [...] A space exists when one takes into consideration vectors of direction, velocities, and time variables. Thus space is composed of intersections of mobile elements." Michel de Certeau, The Practice of Everyday Life, trans. Steven Rendall (Berkeley: University of California Press, 1988), 117. This goes back to ancient distinctions between place (topos), magnitude (megethos) and gap (diastêma) and their close concomitant, time - concepts that are present in medieval philosophy via Aristotle; see John Emery Murdoch, "Infinite Times and Spaces in the Later Middle Ages," in Raum und Raumvorstellungen im Mittelalter, ed. Jan A. Aertsen and Andreas Speer, Miscellanea mediaevalia 25 (Berlin: de Gruyter, 1997), 194-205; Christoph Kann, "Der Ort der Argumente. Eigentliche und uneigentliche Verwendung des mittelalterlichen locus-Begriffs," in ibid., $402-18$. 
177,10 -39; 178,1-179,2), opaque objects like clouds (MF 134,3-4) or various kinds of birds (MF 8,33-9,12; Wolfram's Guot wîp, ich bitte dich minne in MF 9,18-20; Kürenberger's MF 10,17-20; MF 156,13-4).

- Limiting semantic borders: these spaces can be limited by references to God (MF 47,27-8; 92,7-8), death (MF 87,5-6; 129,35-130,2) or other concepts.

- Entities: by producing paradoxical spaces, speaker and addressee are often disintegrated into multiple conflicting entities such as body versus soul (MF 147,4-15; 173,34-174,2), body versus heart and/or will (Wolfram's Sîne klâwen in MF 5,5; MF 42,19-23; 47,9-16 and 25-32;114,35-8; 194,31-3; $215,30-1$ ) or other configurations such as singers versus lovers (MF 133,21 32).

By creating such a matrix of frequently used levels, aspects and elements of spatial paradoxes, we can reconstruct traditionally isolated genres as specific configurations of teleiopoetry. While functional, semantic or communicational approaches often raise serious doubts about the clear-cut distinctiveness of subgenres such as laments over absence or rejection, messenger songs, Dawn Songs or crusading songs, these types may become discernible (and more easily distinguishable) as different combinations of a shared set of spatializing features and aspects. This might enable us to read Minnesang from a more integrated perspective that detects characteristic possibilities and varieties of spatialization rather than categorial generic distinctions. From this perspective, we can not only account for the fact that Minnesingers build upon the same spatializing strategies (though filling them with different possibilities) in both religious and secular songs, such as crusading songs or erotic laments. But we can also understand why many singers seem equally worried about getting too far from or too close to their lady, as Reinmar reflects: "Sî enlât mich von ir scheiden / noch bî ir bestên" (she neither lets me leave her nor stay near her, MF 161,21 -2). Close to his beautiful lady ("bî der schoenen"), Gottfried's singer finds his desire fulfilled but his mind so stupefied ("gar âne sin") that - to his own embarrassment - he cannot speak; as he gains distance, however, his speech returns only at the price of absence (Diu zît ist wunneclîch, III). In Albrecht von Johansdorf, it is the lady herself who points to the paradoxical spatialization of mind and body so frequently employed by crusading songs: "wie wiltu nû geleisten diu beide, / varn über mer und iedoch wesen hie?" (now how do you want to manage both travelling beyond the sea and staying here at the same time? MF $87,15-6)$. We may therefore conclude that this paradoxical spatialization may in fact be more fundamental to courtly poetry than any particular concept of love. 


\section{III. 'Teleiopoiesis' - the Making of Proximity Through Distance}

How can we then explain the fact that teleiopoetry flourishes to such a remarkable extent in medieval culture? A closer look at the theoretical sources of this question is required here. It was Jacques Derrida who first coined the term téléiopoièse, in a seminar series on Politics of Friendship, to characterize a prediction from Nietzsche's Beyond Good and Evil.: "Ach! Wenn ihr wüsstet, wie es bald, so bald schon - anders kommt!" (Alas if only you knew how soon, how very soon, things will be - different!). ${ }^{40}$ For Derrida, this utterance "gets carried away, precipitates and precedes itself, as if its end arrived before the end." ${ }^{41}$ It thus unfolds a 'teleiopoietic' quality which Derrida describes by way of a playful, yet precarious double etymology. On the one hand, referring to Greek

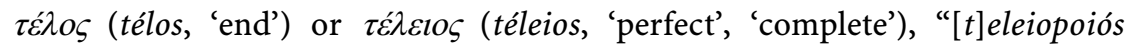
qualifies, in a great number of contexts and semantic orders, that which renders absolute, perfect, completed, accomplished, finished, that which brings to an end." ${ }^{42}$ On the other hand, the prefix of 'teleiopoiesis' resonates with the Greek $\tau \hat{\eta} \lambda \varepsilon$ (têle, 'far'), indicating the opposite aspect of distance:

But permit us to play too with the other tele, the one that speaks to distance and the farremoved, for what is indeed in question here is a poetics of distance at one remove, and of an absolute acceleration in the spanning of space by the very structure of the sentence (it begins at the end, it is initiated with the signature of the other). Rendering, making, transforming, producing, creating - this is what counts $[\ldots] .^{43}$

Hence, 'teleiopoiesis' comprises aspects both of closure and of open contingency, the projection of distant spaces, times, or others and the drawing near of those spaces, times, or others at the same time. Doing 'teleiopoiesis', in the words of Gayatri Chakravorty Spivak, means "to affect the distant in a poiesis an imaginative making - without guarantees." ${ }^{\prime 4}$ Derrida's paradoxical spin on

39 Branching from Derrida's analyses, the term inspired methodological debates on Comparative Literature and post-colonial theory; see, most notably, Gayatri Chakravorty Spivak, Death of a Discipline (New York: Columbia University Press, 2003). For a brief reconstruction of Derrida's and Spivak's use of the term see Corinne Scheiner, "Teleiopoiesis, Telepoesis, and the Practice of Comparative Literature," Comparative Literature 57 (2005), 23945; Eric Hayot, "I/O: A Comparative Literature in a Digital Age," ibid., 219-26, and Ebrahim Moosa, Ghazali and the Poetics of Imagination (Chapel Hill: University of North Carolina Press, 2005), 40-3.

40 Friedrich Nietzsche, Jenseits von Gut und Böse, in Sämtliche Werke. Kritische Studienausgabe, ed. Giorgio Colli and Mazzino Montinari, 15 vols., 2nd ed. (Berlin: de Gruyter, 1999), 5:9-243, 152 (no. 214); translation by George Collins in Jacques Derrida, Politics of Friendship (London: Verso, 1997), 31.

41 Derrida, Politics of Friendship (see note 40), 31.

42 Ibid., 32.

43 Ibid.

44 Spivak, Death of a Discipline (see note 39), 31; see also Gayatri Chakravorty Spivak, "Har- 
the term could be instructive for medievalists' studies on teleiopoetry, as it highlights the productive dynamics of imaginative relations that both reach close and transport distant.

Furthermore, it is by no means an arbitrary choice that Derrida develops his concept in a study on the making of social collectives and friendship. Inverse to each other, collective relations and friendship deal with irreducible paradoxes of intimacy and distance. When medieval teleiopoets privilege the semantics of friendship and its erotic, socio-political or religious discourses, they simply radicalize the general production of social relations by means of literary projection and transport. It might be due to this general distribution of teleiopoetry (and perhaps less motivated by specific concepts of friendship or love) that epistolary literature from monastic contexts, amor de loing in Provençal poetry and Fernliebe in German Minnesang resemble one another to a remarkable degree in some of their poetic techniques and semantics. ${ }^{45}$

This hypothesis links up with older observations and theories in the social sciences and cultural studies. Social relations reproduce in relational and symbolic spaces rather than in homogeneous, absolute container-spaces in the Euclidean or Cartesian sense. ${ }^{46}$ As is also well-established, medieval societies in

lem," Social Text 81 (2004), 113-39 who briefly summarizes "teleopoiesis" as "a reaching toward the distant other by the patient power of the imagination," Ibid., 116.

45 See Katherine Kong, Lettering the Self in Medieval and Early Modern France (Woodbridge: Boydell \& Brewer, 2010), 15-54.

46 See, for instance, Georg Simmel: "Über räumliche Projektionen sozialer Formen," in Gesamtausgabe, ed. Otthein Rammstedt (Frankfurt am Main: Suhrkamp, 1995), 7:201-20. According to Henri Lefebvre, physical space constitutes only a precondition; social space, on the other hand, needs to be produced in order to enable perceptions ("espace perçu"), conceptions ("espace conçu") and living ("espace vécu"); see Henri Lefebvre, The Production of Space (Oxford: Blackwell, 1991); on meaningful spatial relatedness see also Ernst Cassirer, Philosophie der symbolischen Formen. Zweiter Teil: Das mythische Denken, in Gesammelte Werke, ed. Birgit Recki, 29 vols. (Hamburg: Meiner, 2010), 12:98-110. For overviews on spatial concepts in social sciences see Markus Schroer, Räume, Orte, Grenzen. Auf dem Weg zu einer Soziologie des Raums (Frankfurt am Main: Suhrkamp, 2006), 17-181; Martina Löw, Raumsoziologie (Frankfurt am Main: Suhrkamp, 2001); Raumtheorie. Grundlagentexte aus Philosophie und Kulturwissenschaften, ed. Jörg Dünne and Stephan Günzel (Frankfurt am Main: Suhrkamp, 2006), 289-368. For recent approaches towards medieval spatiality, see Marian Füssel and Stefanie Rüther, "Einleitung," in Raum und Konflikt. Zur symbolischen Konstituierung gesellschaftlicher Ordnung in Mittelalter und Früher Neuzeit, ed. Marian Füssel, Christoph Dartmann and Stefanie Rüther, Symbolische Kommunikation und gesellschaftliche Wertesysteme 5 (Münster: Rhema, 2004), 9-18; Elisabeth Vavra, "Einleitung," in Virtuelle Räume. Raumwahrnehmung und Raumvorstellung im Mittelalter. Akten des 10. Symposiums des Mediävistenverbandes, Krems, 24.-26. März 2003, ed. Elisabeth Vavra (Berlin: Akademie Verlag, 2005), 7-16, and the contributions to Projektion - Reflexion - Ferne (see note 9). Although the social production of space is generally acknowledged in historically oriented scholarship, the container model of space is still used in analytical literary studies; as a recent example see Katrin Dennerlein, Narratologie des Raumes, Narratologia 22 (Berlin: de Gruyter, 2009). 
particular have to (re)produce their social structure by means of symbolic spatial practices and performances, inasmuch as they are lacking institutional mechanisms to secure permanent relationships between places, people, and rules of action. Courts, monasteries or cities do not simply 'have' or 'own' fixed locations but need to produce their social space and its extension. ${ }^{47}$

The concept of teleiopoetry can be linked to spatial aspects of socialization with two provisos. It would of course fall short (and only perpetuate a known pitfall of social history) to reduce teleiopoetry to a direct function (either formative or expressive) of social spaces. However, it could be regarded as a symbolic medium for the production of strategies, semantic options and communicative structures that can be used for social spatialization. Secondly, Derrida's notion of 'teleiopoiesis' forgoes terminological precision for the sake of a laborious, "labyrinthine" strategy of reading. ${ }^{48}$ It should be noted, for instance, that Derrida's concept of 'making towards the distant' covers not only spatial, but also temporal and other aspects of distance. So the 'nature' of this space and whether we should call it space at all - requires further theoretical scrutiny. ${ }^{49}$

'Teleiopoiesis' is worth this effort, I would argue, since it surpasses many theories dealing with the social production of space and studies on literary spaces, in that it insists on the productivity of the spatial paradox: the greater the distance, the closer you get. In the case of Rudolf von Fenis this spatial paradox emerges in the interplay between propositional, rhetorical and conceptual distance on the one hand and self-referential poetic structures on the other; in Heinrich von Morungen, we find the spatial paradox emerging from a coercive ontology of limited bodies and unlimited souls. Hence the concept of teleiopoiesis could raise our awareness of the incessant work performed by medieval writers to maintain its balance through projection and approximation. Teleiopoetry may be studied as this production of related distance and its premises.

47 See Simmel, "Räumliche Projektionen," (see note 46), 306-7; Nikolaus Staubach, "Einleitung," in Außen und Innen. Räume und ihre Symbolik, ed. Nikolaus Staubach and Vera Johanterwage, Tradition - Reform - Innovation. Studien zur Modernität des Mittelalters 14 (Frankfurt am Main: Peter Lang, 2007), 7-9.

48 Spivak, Death of a Discipline (see note 39), 27.

49 It may be necessary to replace the (Kantian) categorial vocabulary of space with more integrative approaches; for a language of space allowing for higher phenomenal complexity see, for example, Günter Figal, Erscheinungsdinge. Ästhetik als Phänomenologie (Tübingen: Mohr Siebeck, 2010), 231-81. 


\section{Teleiopoetry as Cultural Practice}

In so doing we should not blur the difference between Derrida's generalizing term téléiopoièse and my usage of the term as a heuristic concept for literary practices. ${ }^{50}$ But can we treat teleiopoetry simply as a literary phenomenon? I would like to argue that we can indeed, although teleiopoetry is not 'simply' or exclusively literary, but rather rooted in cultural practices of spatialization, as we can infer from at least four points.

First: Despite the fact that it is mostly treated within disciplinary confines and labelled by distinct concepts, teleiopoetry is a cross-linguistic and cross-generic phenomenon. This is prominently articulated in Provençal poetry, where the songs of Jaufré Rudel advocate a distant love in which, to recall Leo Spitzer's famous commentary, "l'éloignement est paradoxalement consubstantiel avec le désir de l'union" ("Distance is paradoxically consubstantial with the desire for union"). ${ }^{51}$ Jaufré mentions this spatial paradox in several songs: “D'aquest' amor son tan cochos / Que quant eu vauc ves leis corren, / Vejaire m'es c'a reüsos / Me'n torn e qu'ella m'an fugen" (for (by) this love I am so enflamed that when I go running towards her (it) it seems to me that backwards I turn and that she (it) continues fleeing me) ${ }^{52}$ - so the closer you get ("ves leis corren"), the greater the distance ("m'an fugen"). As in Rudolf von Fenis (MF 82,5-11), the desire of Jaufré's lover in Pro ai del chan essenhadors experiments with mental approximation across spatial distance: "Ma voluntat $s[\mathrm{e}] \cdot \mathrm{n}$ vay lo cors / La nueit e:l dia esclarzitz / Laintz per talant de son cors" (my will [desire] goes off immediately at night and in lighted day there [therein] through desire for her body) ${ }^{53}$ Jaufrés' Lanquan li jorn son lonc en may (written around 1150) unfolds the teleiopoietic

50 This distinction has become less visible in the course of translation. While Derrida's French term "téléiopoièse" combines the ambiguity of closure (téleios) and distance (têle) with the general term of 'making' (poiesis), George Collins's translation renders it as "teleiopoesis", thereby reducing it to the concept of poesy (poesis) [my emphasis]; Spivak, on the other hand, keeps the broader term poiesis, yet reduces its first component to "teleopoiesis" [my emphasis]; see Spivak, Death of a Discipline (see note 39), 31 and elsewhere. For the problems of transliteration and translation see Scheiner, "Teleiopoiesis" (see note 39), 242-4 and Hayot, "Comparative Literature" (see note 39), 221.

51 Spitzer, L'amour de lointain (see note 9), 21; see also Kasten, Frauendienst (see note 31), 83; for an overview on concepts and practices of love of/from distance in Provençal poetry, see Söffner, "Liebe als Distanz" (see note 9).

52 Jaufré Rudel, Quan lo rossinhols el folhos, 2,1 - 4; text and translation from Jaufré Rudel, The Songs of Jaufré Rudel, ed. and trans. Rupert T. Pickens, Pontifical Institute of Mediaeval Studies: Studies and Texts 41 (Toronto: Pontifical Institute of Mediaeval Studies, 1978), $70-1$. On this song, see Söffner, "Liebe als Distanz" (see note 9), 57-69, with further references.

53 Jaufré Rudel, Pro ai del chan essenhadors, 6,1 -3; Jaufré Rudel, Songs (see note 52), 140-1. 
paradox to a whole song. ${ }^{54}$ The long days of May and the song of birds from afar remind the singer of a certain "amor de loing" $(1,4)$, a love from afar:

Ja mais d'amor no'm gauzirai

Si no'm gau d'est' amor de loing,

Qe gensor ni meillor non sai

Vas nuilla part ni pres ni loing.

Tant es sos pretz verais e fis

Qe lai el renc dels Sarrazis

Fos eu per lieis chaitius clamatz.

(Never shall I enjoy love if I do not enjoy this love from afar, for fairer [more noble] nor better do I know anywhere near or far. So much is her [its] worth true and fine that there in the kingdom of the Saracens would I be called, for her sake, captive [wretched]. Jaufré Rudel, Lanquan li jorn son lonc en May II; Rudel, Songs [see note 52], 164-5)

To balance this middle ground "ni pres ni loing" (II,4), Jaufré imagines varying erotic impediments that cause different modalities of love: the singer's depressed mood in remembrance (I), his joy about a love from afar that would withstand captivity in the hands of the infidels (II), frustrating topographical distance (III), that God's grace alone could grant him imaginary conversation (IV), an approach in the guise of a pilgrim (V), his prayer to god (VI) and the hatred of his godfather, who prevents the fulfilment of his wishes (VII). Distance is present even in his wishes for immediate, joyful proximity:

Be·m parra jois quan li qerrai

Per amor Dieu l'amor de loing,

E s'a lieis plai, albergarai

Pres de lieis, si be $m$ sui di loing.

Adoncs parra 1 parlamens fis

Qand drutz loindas er tant vezis

C'ab bels [digz] jauzirai solatz.

(Indeed, joy will appear to me [it will seem a joy to me] when I seek from her, for the love of God, the love from afar, and if it pleases [I please] her, I shall lodge near her, although I am far away [from afar]. Then will conversation seem noble when a far-away lover is so close that I shall enjoy solace with fair [words]. Jaufré Rudel, Lanquan li jorn son lonc en May IV; Rudel, Songs [see note 52], 166-7)

Even from his beloved he seeks "amor de loing"; even if he should get close to her ("pres de lieis"), this could only happen under the conditions of distance ("di loing") - Jaufré thus carefully balances the teleiopoietic connection, its discursive figures of mediation (e.g., the pilgrim of the fifth cobla) and limiting semantics (for example, God). As Jan Söffner has shown in a seminal study, this

54 For full discussions of this song, see Söffner, "Liebe als Distanz" (see note 9), 69-77, and Wyss, "Amour de loin" (see note 9). 
aims less at the 'ennobling' effects of love through longing and absence: "Stattdessen liegt es nahe, 'amor de loing' hier auf seine Räumlichkeit hin zu verstehen" (Instead, here, 'amor de loing' is obviously to be understood through its spatiality $)^{55}$ - a spatiality of bodily and intellectual extension renewed with each cobla, as further substantiated by Ulrich Wyss. ${ }^{56}$ Clearly, the repetitive, infinite dynamics of Jaufré's song, which have frequently been noted by scholars, experiment with the space of teleiopoetry.

Yet teleiopoetry is not confined to French or German courtly poetry. In the urban context of thirteenth-century Italy, Dante's Vita nova recounts how amore inspires the narrator to produce poems as an intermediary dialogue with Beatrice from afar: "Queste parole fa che siano quasi un mezzo, sì che tu non parli a lei immediamente, che non è degno" (let these words be as it were an intermediary so that you do not speak directly to her, for it is not fitting that you should) ${ }^{57}$ As much as he desires Beatrice's presence, he maintains his distance; he sees her, but no more. Even before, Dante had avoided direct, unmediated contact, using another lady as a shield (schermo) between him and Beatrice for several years $:^{58}$ a beautiful screen-lady who veils his secret and secures Dante's teleiopoetry in the urban space as he writes sonnets on Beatrice from afar. Accordingly, Dante is deeply worried when the middle lady of his 'proximity through distance' eventually leaves the city:

La donna co la quale io avea tanto tempo celata la mia volontade, convenne che si partisse de la sopradetta cittade e andasse in paese molto lontano; per che io, quasi sbigottito de la bella difesa che m'era venuta meno, assai me ne disconfortai, più che io medesimo non avrei creduto dinanzi.

55 Söffner, "Liebe als Distanz" (see note 9), 76.

56 On this "Effekt der Verräumlichung", see Wyss, "Amour de loin" (see note 9), 166-9.

57 La vita nuova di Dante Alighieri. Edizione critica, ed. Michele Barbi, (Florence: Bemporad, 1932), 12:8; translation from Dante Alighieri, Vita nuova, trans. Mark Musa (Oxford: Oxford University Press, 2008), 20. The following remarks can only briefly touch the model of mediation and the dynamics of veiled signification that shape Dante's Vita on multiple levels throughout the whole text. They have received extensive critical attention; see, only as a selection, Paul J. Klemp, "The Women in the Middle: Layers of Love in Dante's Vita Nuova," Italica 61 (1984), 185 -94; Winfried Wehle, Dichtung über Dichtung. Dantes 'Vita Nuova': die Aufhebung des Minnesangs im Epos (München: Fink, 1986), esp. 31 - 56; Giuseppe Mazzotta, "The Language of Poetry in the Vita nuova," in Dante: The Critical Complex, ed. Richard Lansing, 8 vols. (New York: Routledge: 2002), 1:93-104; Suzanne Conklin Akbari, Seeing through the Veil: Optical Theory and Medieval Allegory (Toronto: University of Toronto Press, 2004), 116-125; Andreas Kablitz, "Fiktion und Bedeutung. Dantes Vita nova und die Tradition der volkssprachlichen Minnelyrik," in Fiktion und Fiktionalität in den Literaturen des Mittelalters. Jan-Dirk Müller zum 65. Geburtstag, ed. Ursula Peters and Rainer Warning (München and Paderborn: Fink, 2009), 339-62; Lorenzo Mainini, "Schermi e specchi: intorno a 'Vita nova' 2,6-9 e ad alter visioni dantesche,' Critica del testo 14 (2011), 147 - 78.

58 Dante Alighieri, Vita nova (see note 57), 5-6, 48. 
(It became necessary for the lady who had so long helped me conceal my true feelings to leave the aforementioned city and to journey to a distant town; wherefore I, bewildered by the fact that my ideal defence now had failed me, became very dejected, more so than I myself would heave previously believed possible. Dante Alighieri, Vita nova, 7:1, Musa, 11)

As the increased distance ("in paese molto lontano") threatens to unbalance the fragile proximity of teleiopoetry, Dante is quick to find new screens (Chapter IX).

However, teleiopoetry is not limited to vernacular courtly literature, its erotic codes and its urban reception in the late Middle Ages alone. Even beyond lyrical genres, medieval literature seems obsessed with teleiopoietic strategies, semantics and figures such as letter-writing, vision through spatial obstacles, messengers and angels, ${ }^{59}$ travelling, spatial hinges like birds which connect remote spheres and many other phenomena of spatial inclusion and exclusion that produce proximity through distance. Instead of leaving their marital problems at home, Erec and Enide take the task of balancing excess and moderation on an adventurous journey during which they experiment with not just sexual, but spatial and social distance and proximity again and again. All these are examples of teleiopoetry and they demonstrate that we can neither limit teleiopoetry to certain genres nor to the erotic discourse - it pervades political power and social relations of various kinds, from the construction of peripheries filled with monsters to the centres of sacred or urban spaces.

My second point takes one step further: teleiopoetry is not exclusively literary (in the narrower sense), but structures various types of non-fiction texts too, as Franz Josef Worstbrock has recently shown with regard to Latin epistolary literature: "Fernliebe [...] ist nicht auf Dichtung und nicht auf die Begründung einer Liebesbeziehung zu einer Frau beschränkt" ("Fernliebe is not restricted to poetry and to the substantiation of a love relationship with a lady"). ${ }^{60}$ On the

59 Messengers and angels are perhaps prime examples of the cultural figure of teleiopoiesis: see Sybille Krämer, Medium, Bote, Übertragung. Kleine Metaphysik der Medialität (Frankfurt am Main: Suhrkamp, 2008), 108 - 37; with regard to troubadour poetry, see Söffner, "Liebe als Distanz" (see note 9), 71n37; for the institution of messengers since early medieval diplomatic practice, see Volker Scior, "Bemerkungen zum frühmittelalterlichen Boten- und Gesandtschaftswesen," in Der frühmittelalterliche Staat - europäische Perspektiven, ed. Walter Pohl, Forschungen zur Geschichte des Mittelalters 16 (Wien: Österreichische Akademie der Wissenschaften, 2009), 315-30. Horst Wenzel has stressed the importance of the bodily presence of the messenger in medieval face-to-face communication, but also his capacity to cross distance: see Horst Wenzel, "Boten und Briefe. Zum Verhältnis körperlicher und nichtkörperlicher Nachrichtenträger," in Gespräche, Boten, Briefe. Körpergedächtnis und Schriftgedächtnis im Mittelalter, ed. Horst Wenzel, Philologische Studien und Quellen 143 (Berlin: Schmidt, 1997), 86 - 105, and "Vom Körper zur Schrift. Boten, Briefe, Bücher," in Performativität und Medialität, ed. Sybille Krämer (München: Fink, 2004), 269-91.

60 Worstbrock, "Fernliebe” (see note 16), 141. Against Wenzel's "Fernliebe” (see note 16), 
basis of ancient examples (e.g., Paris' letter to Helen in Ovid's Heroides, no. 16; letters by Saint Jerome and Quintus Aurelius Symmachus), the motif of 'love without contact' flourishes in Latin epistolography from early twelfth to the end of the seventeenth century, where it becomes a laudatory topos of the newly constituted art of letter writing (ars dictandi). In his Praecepta dictaminum (around 1115), Adalbertus Samaritanus writes: "Bonorum frequens astipulatio de tuis sanctis moribus in hoc me desiderium provocavit, ut amicitias tuas ardenter exoptem" (the common judgment of good people on your perfect manners has aroused my burning desire for your friendship).$^{61}$ Boncompagno da Signa (around 1170 - 1240) instructs those who seek to love women they have never seen before ("quidam enim illas amare appetunt, quas nunquam viderunt") in the proper art of letter writing (Rota Veneris). ${ }^{62}$ Not all of the samples identified by Worstbrock as epistolary Fernliebe are cases of teleiopoetry - many of them constitute simple contradictions of distance and proximity, but not paradoxes (in Spitzer's sense). Even if the glory and perfection of the praised addressee become present and induce love in the mind of the writer over the greatest distance, the opposite does not necessarily hold true: presence does not generate the need for distance in turn. ${ }^{63}$ Nevertheless, Worstbrock's remarkable examples clearly indicate that medieval rhetoric utilizes the interlacing of distance and proximity well beyond fictional discourse.

My third point on why we should investigate teleiopoetry as a cultural

Worstbrock objects: "Es ist im Gegenteil zweifelhaft, ob Fernliebe als ein signifikanter Liebestypus höfischer Epik [...] überhaupt gelten kann" (ibid.). This holds true only for the narrower concept of distance love - teleiopoietic practices in the wider sense are indeed present in the courtly romance.

61 Adalbertus Samaritanus, Praecepta dictaminum, ed. Franz-Josef Schmale, Monumenta Germaniae Historica. Quellen zur Geistesgeschichte des Mittelalters 3 (Weimar: Böhlau, 1961), 43 (letter 1), quoted in Worstbrock, "Fernliebe" (see note 16), 150.

62 Magister Boncompagno, Rota veneris. Ein Liebesbriefsteller des 13. Jahrhunderts, ed. Friedrich Baethgen, Texte zur Kulturgeschichte des Mittelalters 2 (Rome: Regenberg, 1927), 12.

63 This is also mirrored by the distinction Worstbrock proposes to distinguish between letters that speak of continuing distance ("die räumliche Ferne dauert an") and letters that look back on distance love after successful encounters: "In der anderen Version liegt die Fernliebe zum Zeitpunkt der brieflichen Gesprächsaufnahme bereits zurück, ist die ehemals ferne Person durch Reise oder gelungene Suche gefunden, der Schritt vom Hören zum Sehen getan, die vernommene Rühmung durch Augenschein bestätigt oder gar übertroffen." Worstbrock, "Fernliebe" (see note 16), 147. For this second type, distance is only transitory, not constitutive (and therefore: not paradoxical); it is not "Bedingung der Möglichkeit von Nähe" (Wyss, "Amour de loin" [see note 9], 162) or "Liebe als Distanz" (Söffner, my emphasis). Therefore, the song of Meinloh von Sevelingen (MF 11,1) Worstbrock quotes as a link between Latin epistolography and Minnesang does not refer to the paradox of teleiopoetry: "Verharren in gemessener Distanz ist dem Mann hier nicht auferlegt, im Gegenteil: das Gefunden- und Erblickthaben suggerieren Nähe der Begegnung." Worstbrock, "Fernliebe" (see note 16), 150-51. 
practice: teleiopoetry represents only one special case of a general production of proximity through distance that is cross-medial. It can also be found in nontextual images. Splendid examples can be found in the Codex Manesse. While some images utilize architecture to depict pure distance (e.g., fol. 17r, 42r or $192 \mathrm{v}$ ) and others completely dispense with separating architecture to depict pure intimacy (e. g., 70v, $179 \mathrm{v}$ or $249 \mathrm{v}$ ), several images combine both options. In the images of Leuthold von Seven or Stamheim (fig. 1-2), lovers and ladies are positioned within close reach, but at the same time rendered remote by media of distance (birds, letters, towers). The images of Rubin and Kristan von Hamle utilize more sophisticated, even eccentric technology to produce this distant intimacy (fig. 3-4): lovers shoot their scroll by crossbow or get winched in a freight elevator by their lady, although their spatial distance is ridiculously small. This clearly exceeds spatial realism: as we can see in contrast to less ambivalent images, the Codex Manesse also highlights the spatial paradox in some of its images.
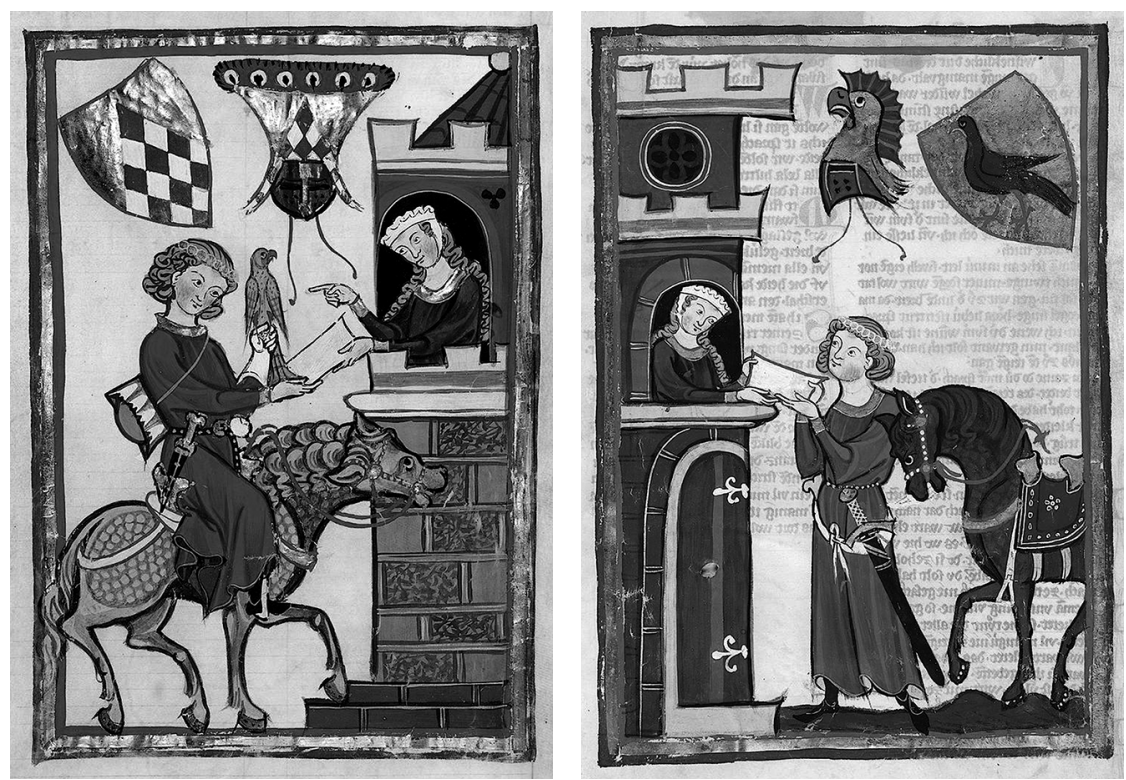

Fig. 1 -2: Teleiopoiesis involving writing, architecture... (on the left: Leuthold von Seven; on the right: von Stamheim; Heidelberg, University Library, cpg 848, fol. 164v / fol. 261r)

My fourth point: teleiopoietic paradoxes govern not just the structure of teleiopoietic media (first-order perspective), but also practices and concepts of disciplines that govern their treatment (second-order perspective). From Hugh of St Victor to Erich Auerbach, from precepts for developing memoria in ancient 
and medieval rhetoric ${ }^{64}$ to Nietzsche, Derrida and Spivak: numerous strategies of speech, of reading and intellectual cultivation methodically rely on teleiopoiesis, or the production of closeness under the conditions of remoteness. A cultural history of teleiopoiesis becomes visible which - despite significant changes in media and semantics - has developed a remarkable longue durée.
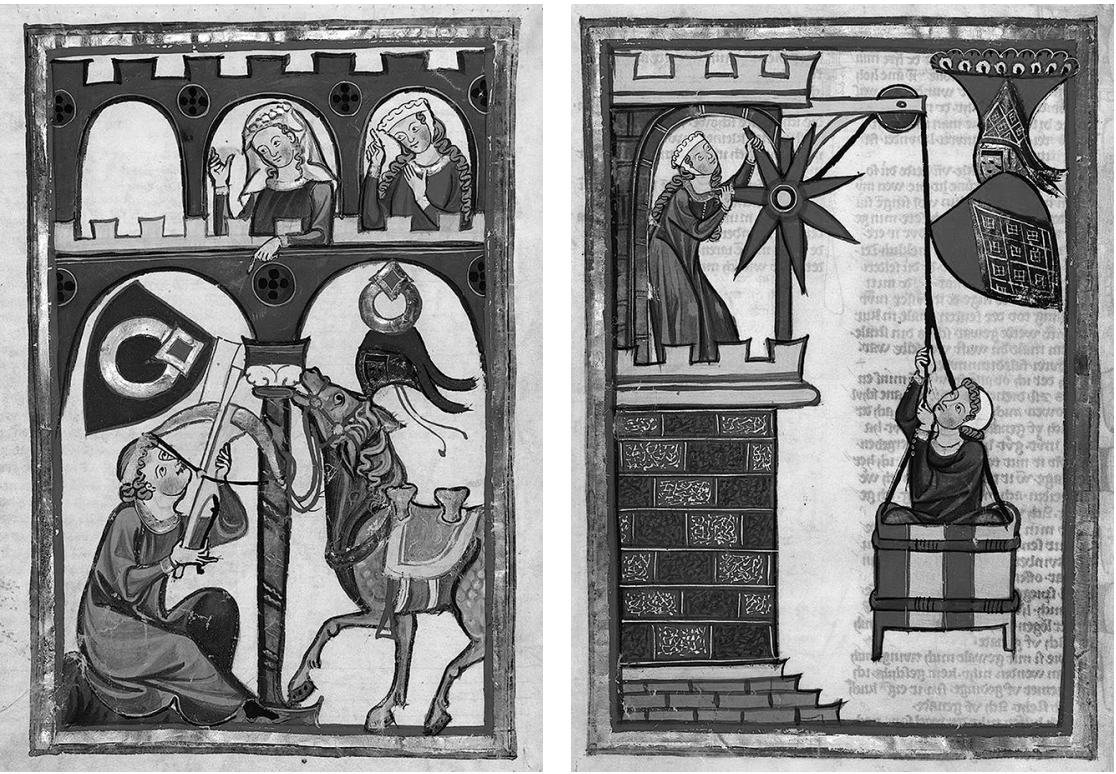

Fig. 3-4: ... or more sophisticated technology (on the left: Herr Rubin; on the right: Kristan von Hamle; Heidelberg, University Library, cpg 848, fol. 169v / fol. 71v).

My fifth and last point may be articulated best in reply to universalist objections: Isn't medieval culture as a whole based upon the religious anthropology of human exile after the fall (as in Hugh) or upon the universal cosmology of correspondence, i. e. on premises that lend teleiopoietic aspects to all practices? And isn't all literature teleiopoiesis (going back to the primal figure of the messenger, as Jan Assmann ${ }^{65}$ would have it) ${ }^{66}$ Isn't all communication based on paradoxes of distance and proximity $?^{67}$ I would argue that we should neither

64 For the spatialization of memory in medieval rhetoric, see Rolf Schönberger, "Der Raum der memoria," in Raum und Raumvorstellungen im Mittelalter (see note 38), 471-488; on the space of medieval topics, see Kann, "Ort der Argumente" (see note 38).

65 See Jan Assmann, Das kulturelle Gedächtnis. Schrift, Erinnerung und politische Identität in frühen Hochkulturen, 5th ed. (München: Beck, 2005), 22.

66 See Spivak, Death of a Discipline (see note 39), 34: "I am grateful to Jacques Derrida for the word [teleopoiesis], which allows us to suspect that all poiesis may be a species of teleopoiesis."

67 In particular, the concept of love from afar is often generalized: "Le lointain est un élèment 
overstretch the concepts of teleiopoetry/teleiopoiesis nor deny the differences of their textual (or other) representations. Mere contradictions or dialectics of distance and proximity do not necessarily have to take the form of paradoxes; conversely, not every paradox of desire is spatialized. Ancient versions of distant love appear less paradoxical than medieval teleiopoetry ${ }^{68}$ From a modern perspective, however, the media of medieval teleiopoets may seem more specialized (and their paradoxes therefore more easily visible) than the teleiopoiesis of modern global intimacy, standardized and made publicly available by Skype. If we acknowledge that teleiopoetry is rooted in cultural logic this does not imply that cultures of teleiopoiesis are invariant, that they display the same elements or that they keep their paradoxes constantly visible to the same degree. ${ }^{69}$ This allows for different teleiopoietic phenomena and practices, of which literary communication is but a part - albeit a fascinating one.

\section{Between Absence and Presence - Towards a Middle Ground}

In conclusion, we may indeed expect new benefits from the study of teleiopoetry. With ever increasing distance both from the semiotics of deconstruction and from recent debates on 'presence cultures', we may begin to see that both projects equally misjudged medieval spatiality. While deconstruction overemphasized the spatializing and temporalizing effects of signs, recent advocates of 'presence cultures' polemically narrowed our view to only the closest, if not immediate proximity in space. Theoretical desire for difference, however, like the desire for presence, evades the paradoxical spaces so forcefully articulated by the texts, images and practices examined above; or to recall Reinmar once more: "Sî enlât mich von ir scheiden / noch bî ir bestên" (she neither lets me leave her nor stay near her, MF 161,21-2). Teleiopoetry offers an uncharted third option towards a literary theory of social space that could embrace this paradox - of embodied presences obsessed with the co-production of distance.

nécessaire de tout amour, aussi nécessaire que le contact - ces troubadours ont en somme senti la selige Sehnsucht de Goethe [...]" (Spitzer, L'amour de lointain [see note 9], 16); with an anthropological undertone, Worstbrock sees "die menschliche Spezies so anfällig" for love from afar. Worstbrock, "Fernliebe" (see note 16), 137.

68 See the comparative study by Patrizia Onesta, "L'amor de lonh de Jaufre Rudel e il longinquus amor di Properzio," Quaderni di filologia e lingue romanze 12 (1997), 89-109; Söffner, "Liebe als Distanz" (see note 9), 69.

69 These differences become most evident in trans-cultural reception of specific models of teleiopoetry; see, for instance, Angelica Rieger, "Amour de loin. Über die Geschicke eines schicksalhaften Motivs: Amin Maalouf und Jaufre Rudel," in Raumerfahrung - Raumerfindung. Erzählte Welten des Mittelalters zwischen Orient und Okzident, ed. Laetitia Rimpau and Peter Ihring (Berlin: Akademie Verlag, 2005), 291 - 312. 